Prepared in cooperation with the

Lower Platte South Natural Resources District, the Lower Platte North Natural Resources District, the Papio-Missouri River Natural Resources District, and the Lower Platte River Corridor Alliance

\title{
Is Septic Waste Affecting Drinking Water From Shallow Domestic Wells Along the Platte River in Eastern Nebraska?
}

\author{
By Ingrid M. Verstraeten1, Greg S. Fetterman2, Sonja K. Sebree³, M.T. Meyer ${ }^{4}$, and T.D. Bullen ${ }^{5}$
}

\section{Significant Findings}

The quality of drinking water from shallow domestic wells potentially affected by seepage from septic systems was assessed by analyzing water samples for substances derived from septic systems. The effects of septic systems on water from domestic wells was demonstrated using several tracers including bacteria, virus indicators, dissolved organic carbon, nitrogen species, nitrogen and boron isotopes, and organic compounds such as prescription and nonprescription drugs. Domestic wells seemed to be most vulnerable to septic-waste contamination when they were sand-point wells within 100 feet of a septic system and were less than 45 feet deep in a shallow, thin aquifer.

\section{Introduction}

More than 100 million people in the United States use ground water as their source of drinking water (Tuthill and others, 1998), and about one-third of the rural and water-front population ( 25 to 30 percent of the households) in the United States uses septic systems for wastewater disposal (Robertson and others, 1991; McAvoy and others, 1994; U.S. Environmental Protection Agency, 2000). Septic tanks serve primarily as settling chambers removing solids from the sewage (fig. 1). In sand and gravel aquifers characterized by large pore sizes that allow for relatively easy and rapid transport of water and contaminants, concentrated plumes of dissolved constituents from septic systems can occur in the shallow part of the aquifer and can affect the quality of drinking water withdrawn from domestic wells. In Nebraska, a large number of shallow sand-point wells are used to obtain drinking water in private households, even though their construction for consumptive uses has been banned since 1987 (Nebraska Department of Health and Human

\footnotetext{
${ }^{1}$ U.S. Geological Survey, 8987 Yellow Brick Road, Baltimore, MD 21237.

2 Lower Platte River Corridor Alliance, Lincoln, NE 68501.

${ }^{3}$ U.S. Geological Survey, Federal Building, Centennial Mall North, Room 406, Lincoln, NE 68508.

${ }^{4}$ U.S. Geological Survey, 4821 Quail Crest Place, Lawrence, KS 66049.

${ }^{5}$ U.S. Geological Survey, Building 15, McKelvey Building, Menlo Park, CA 94025 .
}

Services, 2002). Sand-point and cased wells within 15 feet of septic systems are used for drinking-water supplies in a few cases.

A study conducted by the U.S. Geological Survey (USGS), in cooperation with the Lower Platte South Natural Resources District (NRD), the Lower Platte North NRD, the Papio-Missouri River NRD, and the Lower Platte River Corridor Alliance, was done in 2001 and 2002 to assess the quality of drinking water from shallow domestic wells potentially affected by seepage from septic systems. Water samples were analyzed for traces of certain substances that indicate the presence of water and constituents from septic systems.

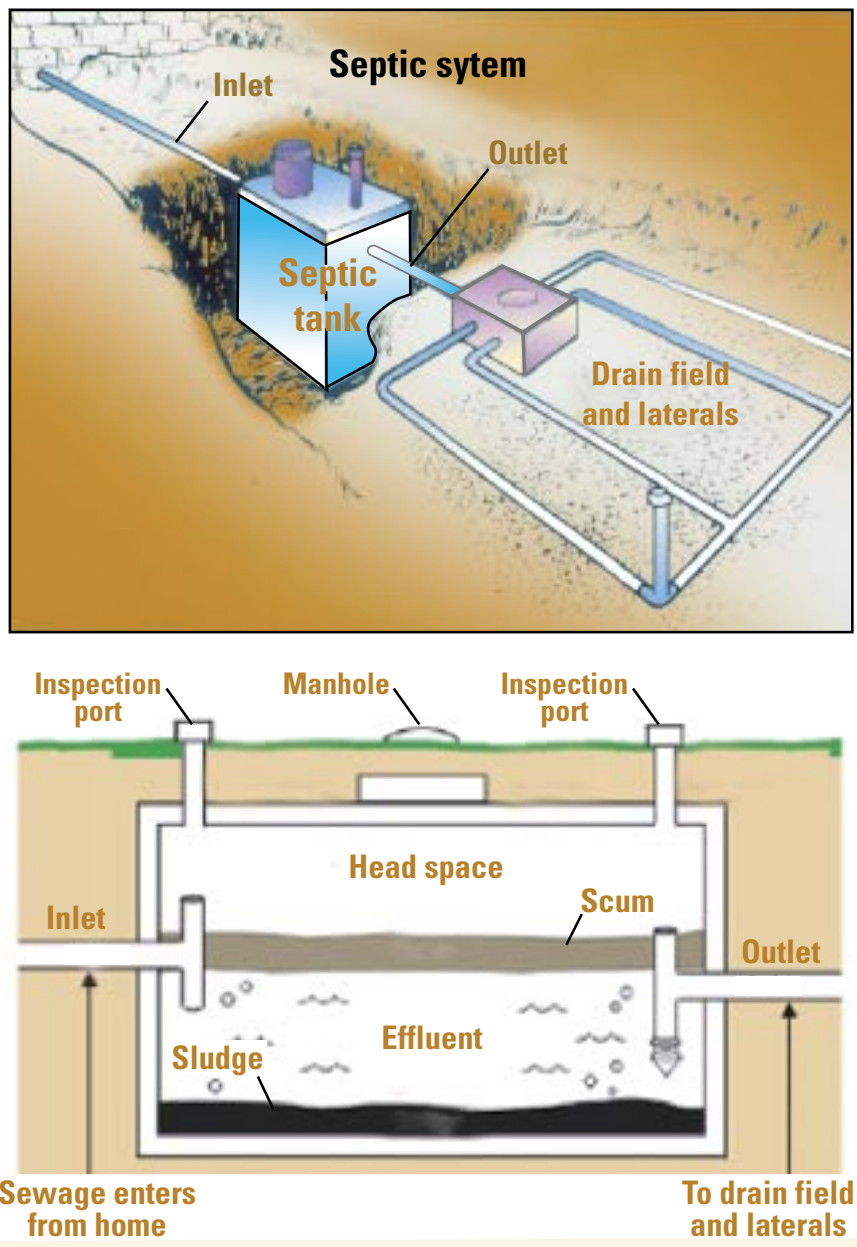

Figure 1. Diagram of a typical septic system. 


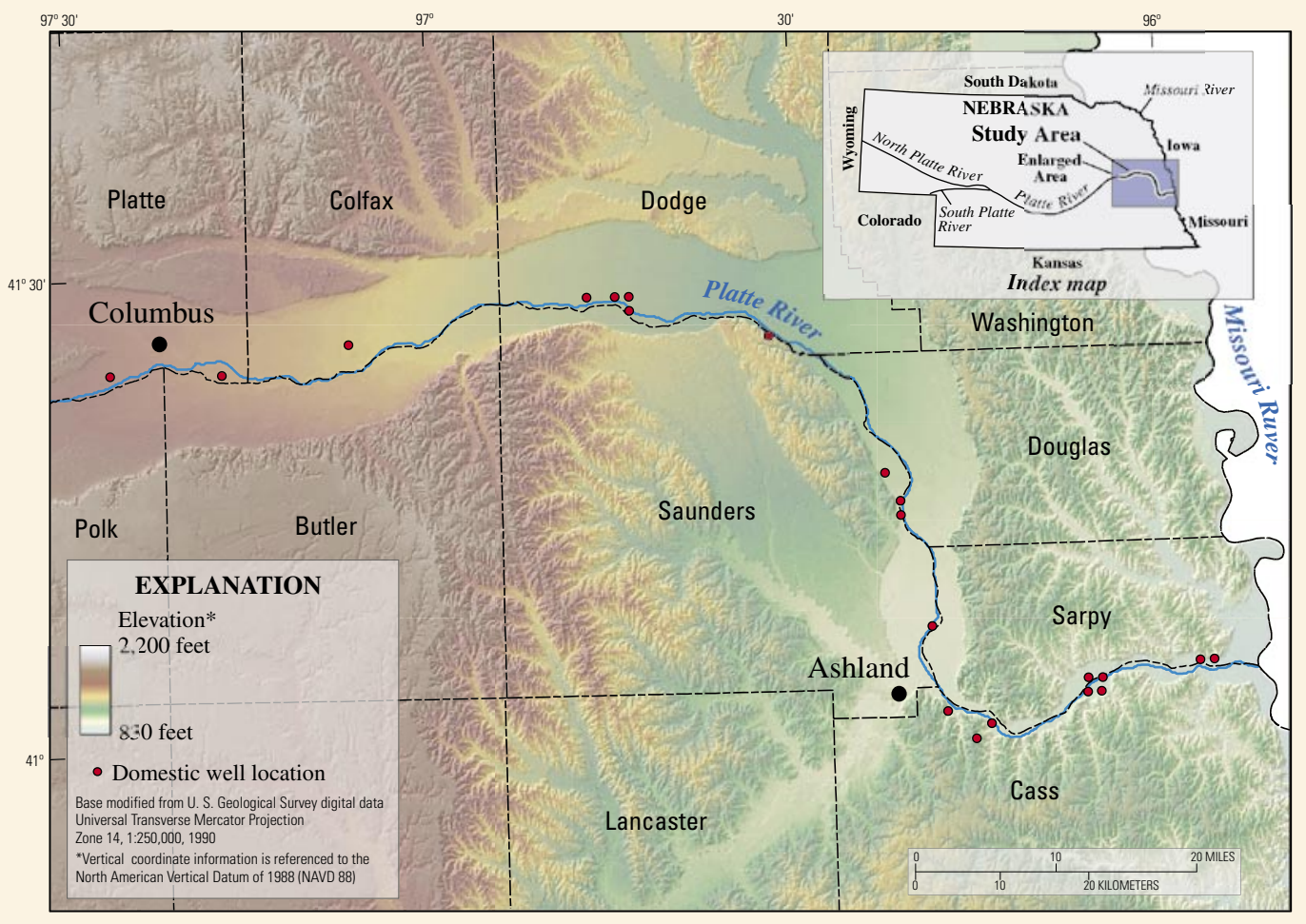

Figure 2. Study area showing general location of shallow domestic wells.

The study area covers approximately 300 square miles in eastern Nebraska extending from Columbus to the Platte River's confluence with the Missouri River and is defined as the 100year flood plain plus a 1-mile buffer on both sides of the Platte River (fig. 2). In the study area, depth to the water table generally is less than 10 feet. Wells are completed in sand and gravel deposits along the river. Some silt and clay also occur at depths of less than 100 feet.

Water samples were collected from 26 domestic wells

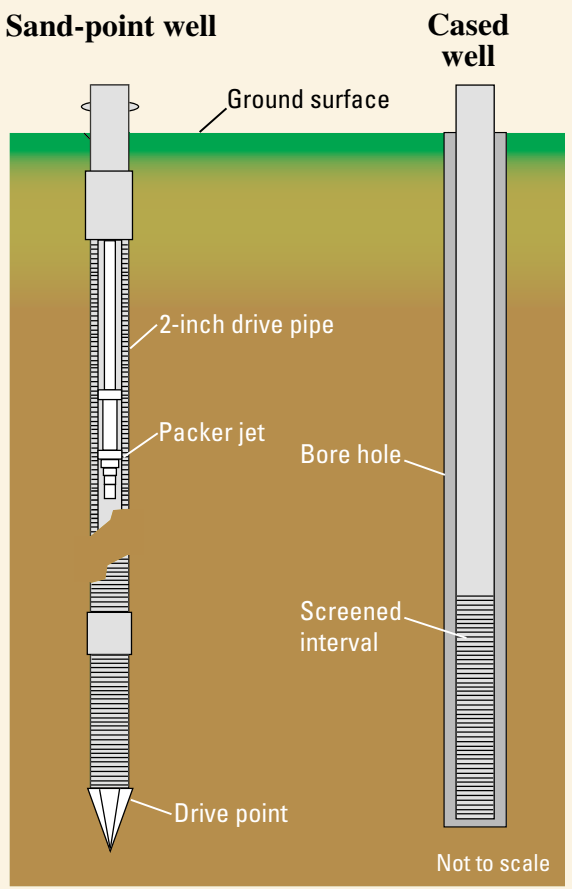

Figure 3. Diagrams of a sand-point well and a cased well such as those typically used in the study area. including both sandpoint (no casing) and cased (with casing) wells (see fig. 3). Wells less than 120 feet deep and within 250 feet of a septic tank were selected within the study area and were sampled when permission from the well owners could be obtained. The water samples were analyzed for bacteria, coliphages (indicators of viruses), forms of nitrogen, and nitrogen and boron isotopes (isotopes are different forms of an element with the same nucleus but differing number of neutrons), prescription and nonprescription drugs, and organic contaminants thought to be present in wastewater. These and other tracers are useful for determining whether drinking water from domestic wells has been affected by water and constituents from a septic system. Samples were analyzed at the Nebraska Department of Health, the USGS National Water Quality Laboratory, and several USGS research laboratories.

\section{What We Found Out}

The study illustrates that shallow wells, whether sandpoint wells or cased wells, can be affected by septic waste if constructed near a septic field, the water table is shallow, and the saturated media consist mainly of sand and gravel. The study results also indicate that bacteria and nitrate concentrations may not always be the best indicators of contamination of drinking water with water and constituents from septic systems and that other indicators may be more valuable in some cases.

\section{Bacteria and Viruses}

Bacteria, commonly used as indicators of fecal contamination, were not detected. The lack of detections indicates that the time required for water to travel from the drain field to the well may have been long enough to allow bacteria to die or adsorb to sediment because of the presence of iron or ammonium (Gerba and Bitton, 1984). Indicator viruses (male-specific coliphages) were detected in 2 of 19 samples. The detections of male-specific coliphages in these two water samples indicate the presence of fecal contamination in water, perhaps due to short traveltimes from the drain fields to the wells.

\section{Nitrogen, Oxygen, and Boron Isotopes}

Nitrogen species can change from one compound to another through biochemical reactions during infiltration and movement within the sediment as shown in figure 4 . Water samples from 4 of 26 wells exceeded the U.S. Environmental Protection Agency's Maximum Contaminant Level of 10 milligrams per liter of nitrate as nitrogen $\left(\mathrm{NO}_{3}{ }^{-}-\mathrm{N}\right)$ (U.S. Environmental Agency, 2000) (table 1).

When oxygen is abundant in the ground water, ammonia changes to nitrate over short distances through nitrification. In the absence of oxygen in the ground water, denitrification can occur, and nitrate is changed to nitrogen gas (fig. 4). In water from 12 of 19 wells, the presence of ammonia may indicate that the distances from septic tank to domestic well were short enough that ammonia did not have the opportunity to be transformed to nitrate or nitrogen gas in these cases. In water from 6 of 19 other wells, the absence of ammonia and presence of 
[MRL, minimum reporting level; $\mathrm{ft}$, feet; --, not applicable; $\mathrm{mg} / \mathrm{L}$, milligrams per liter; $\mu \mathrm{S} / \mathrm{cm}$, microsiemens per centimeter at 25 degrees Celsius; <, less than]

\begin{tabular}{|c|c|c|c|c|c|c|}
\hline $\begin{array}{c}\text { Constituent } \\
\text { (unit of measure) }\end{array}$ & MRL & $\begin{array}{c}\text { Number } \\
\text { of samples }\end{array}$ & Minimum & Mean & Median & Maximum \\
\hline Well depth (ft) & -- & 26 & 15 & 34 & 29 & 100 \\
\hline $\begin{array}{l}\text { Distance of well to laterals of } \\
\text { septic drain field (ft) }\end{array}$ & -- & 26 & 25 & 85 & 65 & 250 \\
\hline Dissolved oxygen (mg/L) & 0.05 & 25 & .06 & 1.12 & .17 & 12.0 \\
\hline $\mathrm{pH}$ (standard units) & .20 & 26 & 6.3 & 7.2 & 7.2 & 7.8 \\
\hline Specific conductance $(\mu \mathrm{S} / \mathrm{cm})$ & & 26 & 285 & 550 & 570 & 710 \\
\hline $\begin{array}{l}\text { Organic carbon, dissolved } \\
\quad(\mathrm{mg} / \mathrm{L})\end{array}$ & .20 & 14 & .5 & 2.8 & 3.1 & 4.3 \\
\hline Ammonia as nitrogen $(\mathrm{mg} / \mathrm{L})$ & .04 & 19 & $<.04$ & .40 & .17 & 1.39 \\
\hline Nitrate as nitrogen $(\mathrm{mg} / \mathrm{L})$ & .05 & 26 & $<.05$ & 4.39 & $<.05$ & 38.7 \\
\hline Nitrite as nitrogen $(\mathrm{mg} / \mathrm{L})$ & .006 & 19 & $<.006$ & .004 & $<.006$ & .09 \\
\hline
\end{tabular}

nitrate in water are consistent with sufficient transport time and oxygen being available to change ammonia to nitrate through nitrification. In water from 1 of 3 wells, the absence of nitrate and presence of nitrogen gas are consistent with complete conversion of nitrate to nitrogen gas through denitrification. Finally, at two locations, ground water had intermediate oxygen concentrations with both nitrate and nitrogen gas present indicating that the denitrification process was incomplete.

Ammonia concentrations seem to be related to well type, well depth, and distance of the well to the laterals of a septic system. The shallower the sand-point well and the shorter the distance from this well to a septic system drain field, the higher the concentrations of ammonia (fig. 5).

Typically, water affected by wastewater has an isotopic value of boron of +5 per mil or less (Vengosh and others, 1994). In this study, two of five samples suspected to be affected by seepage from septic systems on the basis of nitrogen concentrations, nitrogen isotopes, organic carbon concentrations, general hydrogeologic and land-use setting, and well construction had values of -0.2 and 0.7 per mil consistent with the presence of septic effluent.

\section{Organic Compounds}

Prescription and nonprescription drugs can be indicators of wastewater contamination in water from wells. However, these organic compounds can be biodegraded or can be adsorbed to aquifer media. Eight nonprescription drugs were detected in water from 12 of 19 domestic wells at concentrations of as much as 0.13 microgram per liter. There are no Maximum Con-

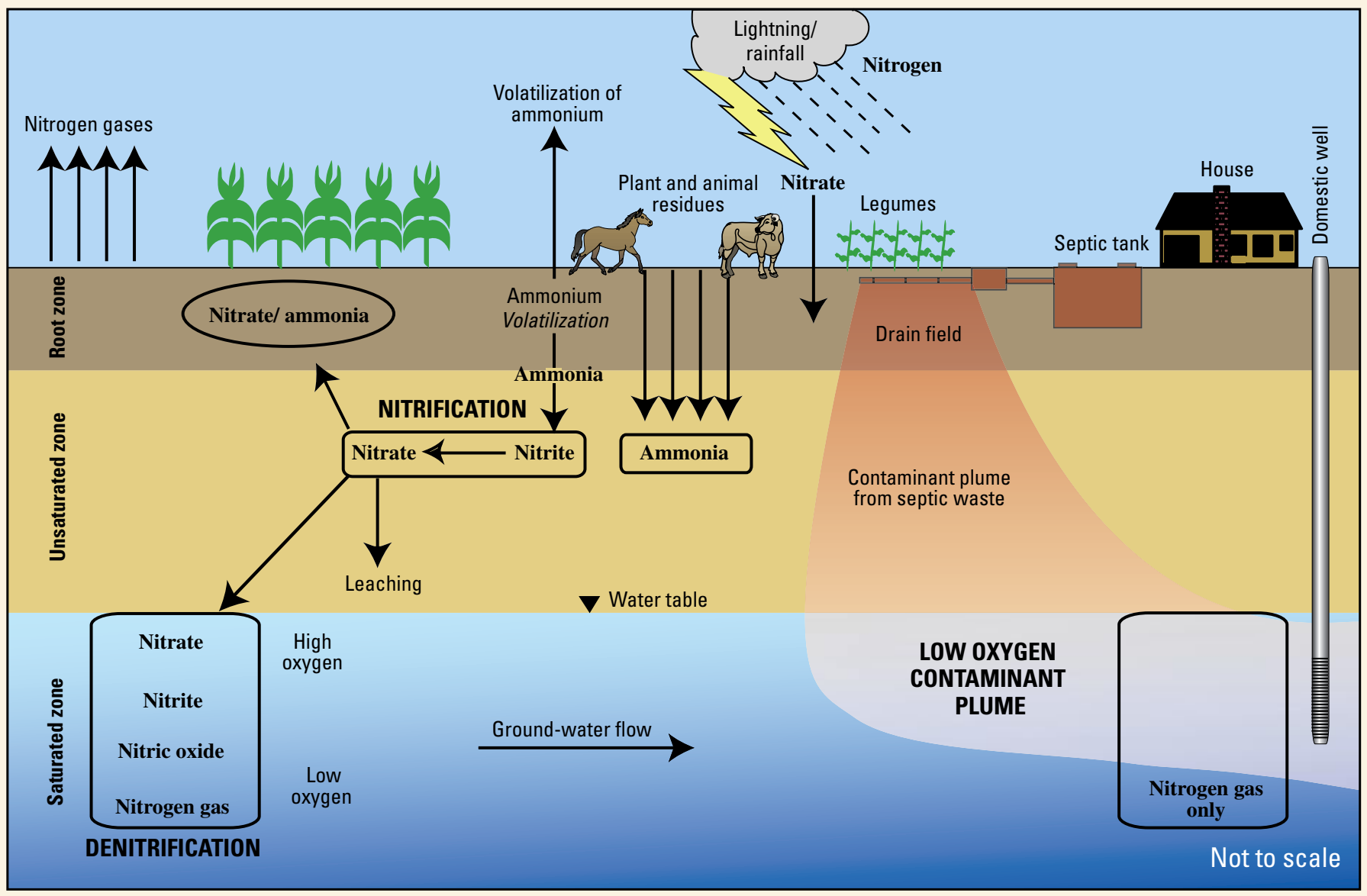

Figure 4. The nitrification and denitrification processes (from Havlin and others, 1999, p. 87. Adapted by permission of Pearson Education, Inc., Upper Saddle River, New Jersey). 


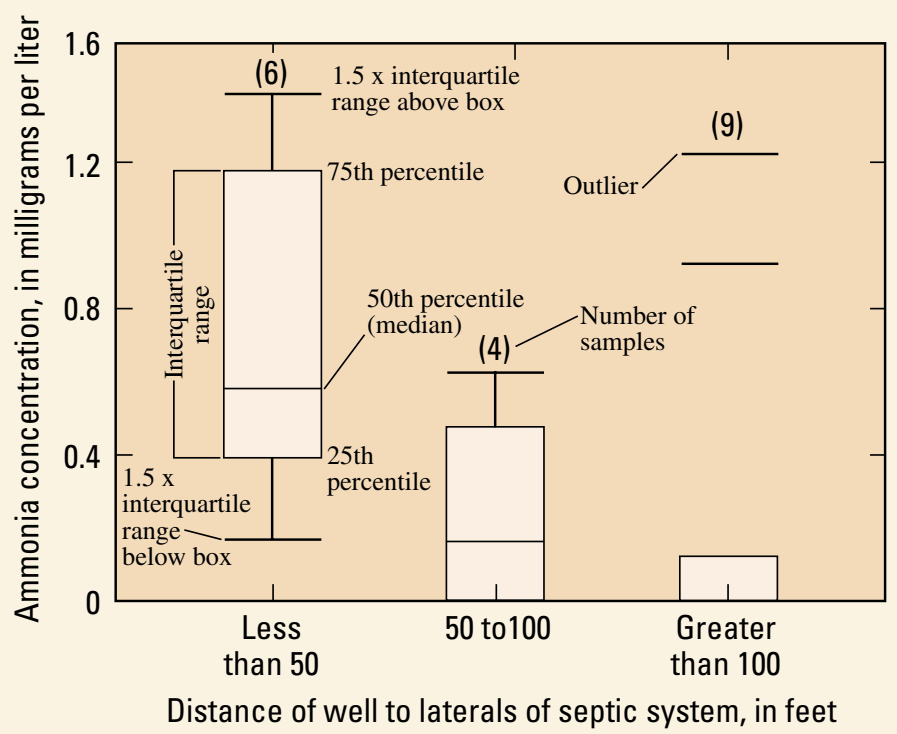

Figure 5. Ammonia concentration by distance of well to laterals of septic system.

taminant Levels for drinking water established by the U.S. Environmental Protection Agency for these compounds. However, occurrence of these contaminants in water from a domestic well can indicate the presence of local septic waste in the drinking water of the household. Whether the source is the owner's own septic field or a neighbor's septic field was not resolved during this study.

Antibiotics were detected in water from 3 of 26 shallow domestic wells. These detections occurred in developments at sandpit lakes or small towns. At these three locations, residences have their own water supply and septic systems and are located far from animal feeding operations. Antibiotics that were detected included ciprofloxacin, enrofloxacin, sarafloxacin, sulfamethoxazole, trimethoprim, and a degradation product of erythromycin. These antibiotics generally are used by humans, but at times also are used to prevent disease in livestock at animal feeding operations. Concentrations varied from traces of ciprofloxacin to 0.75 microgram per liter of an erythromycin degradation product.

\section{What the Results Mean}

Water from several domestic wells contained tracers that were probably derived from seepage from septic systems. Water from domestic wells completed in a shallow (depth to water less than 10 feet) were most likely to show evidence of an effect by seepage from a septic system and seemed to be more vulnerable to septic-waste contamination if they were sand-point wells within 100 feet of a septic-tank system or were less than 45 feet deep. Results from this study indicate that drinking water from some domestic wells in sandy soil with a shallow aquifer that are close to septic drain fields may be affected by seepage from septic systems. Under these conditions, lot sizes, densities of septic-tank systems, and well construction could be evaluated to prevent contamination of drinking water with septic waste.

\section{Acknowledgments}

The authors thank the well owners for participating in the project and giving permission to sample their domestic wells. We also acknowledge the support from the Nebraska Department of Health, the constructive comments of many other Nebraska State and local agencies, and the contributions of Matt Landon, JohnKarl Böhlke, Michael Doughten, Steven Zaugg, and Jeffrey Cahill of the USGS.

\section{References}

Gerba, C.P., and Bitton, Gabriel, 1984, Microbial pollutants-their survival and transport pattern to groundwater, in Bitton, Gabriel, and Gerba, C.P., eds., Groundwater pollution microbiology: New York, John Wiley and Sons, p. 65-88.

Havlin, J.L., Tisdale, S.L., Nelson, W.L., and Beaton, J.D., 1999, Soil fertility and fertilizers - an introduction to nutrient management: Upper Saddle River, New Jersey, Prentice Hall, 499 p.

McAvoy, D.C., White, C.E., Moore, B.L., and Rapaport, R.A., 1994, Chemical fate and transport in a domestic septic system-sorption and transport of anionic and cationic surfactants: Environmental Toxicology and Chemistry, v. 13, no. 2, p. 213-221.

Nebraska Department of Health and Human Services, 2002, Regulations governing water well construction, pump installation and water well decommissioning standards: Department of Health and Human Services Regulation and Licensure, Title 178B, chap. 12, sec. 004.01.

Robertson, W.D., Cherry, J.A., and Sudicky, E.A., 1991, Ground-water contamination from two small septic systems on sand aquifers: Ground Water, v. 29, no. 1, p. 82-92.

Tuthill, M.S., Meikle, D.B., and Alavanja, M.C.R., 1998, Coliform bacteria and nitrate contamination: Environmental Health, April 1998, p. 16-20.

U.S. Environmental Protection Agency, 2000, Current drinking water standards - national primary and secondary drinking water regulations: Office of Ground Water and Drinking Water, accessed December 27, 2000, at URL: http// www.epa.gov/safewater/standards.html

Vengosh, A., Heumann, K.G., Juraske, S., and Kasher, R., 1994, Boron isotope application for tracing sources of contamination in groundwater: Environmental Science and Technology, v. 28 , p. 1968-1974.

For further information contact:

U.S. Geological Survey Federal Building, Room 406 100 Centennial Mall North

Lincoln, NE 68508

(402) 437-5082

USGS Nebraska District Home Page: http://ne.water.usgs.gov 